\title{
FRAKTURA KUKA: USPOREDBA NALAZA KONVENCIONALNE RADIOGRAFIJE I KOMPJUTORIZIRANE TOMOGRAFIJE
}

\author{
Marko Krpan, Miro Miljko \\ Fakultet zdravstvenih studija Sveučilišta u Mostaru \\ Rad je primljen: 6.4.2015. Rad je revidiran: 22.4.2015. Rad je prihvaćen: 30.4.2015.
}

\section{SAŽETAK}

UVOD: Zglob kuka je jedan od najvažnijih zglobova i ujedno najveći zglob ljudskog tijela. On ima nezaobilaznu ulogu u razvoju i očuvanju pravilne arhitekture cjelokupnog lokomotornog sustava, odnosno statike i simetrije tijela ljudskog tijela. Prijelomi kuka su danas izuzetno značajan osobni, javno-zdravstveni i obiteljski problem jer u velikoj mjeri narušavaju kvalitetu života pacijenata, dok s druge strane iziskuju znatne troškove zdravstvenog sustava. Cilj istraživanja bio je usporediti vrijednost konvencionalne radiografije i kompjutorizirane tomografije u dijagnostici i radiološkoj opservaciji fraktura i ozljeda kuka.

ISPITANICI I METODE: Za potrebe završnog rada provedeno je retrospektivno istraživanje na Zavodu za radiologiju Sveučilišne kliničke bolnice Mostar u Mostaru. Provedeno istraživanje odnosi se na vremenski period od 10.01.2014.g. do 21.08.2014.godine. Istraživanje je obuhvaćalo ukupno 40 pacijenata kod kojih je primjenjena radiološka obrada kuka. Svim pacijentima je učinjen specijalistički pregled ortopeda, RTG i MSCT pregled te je klinički i dijagnostički dokazana fraktura kuka.

REZULTATI: Rezultati ukazuju na da frakture kuka češće pogađaju mušku populaciju starije životne dobi. Najčešći uzrok nastanka frakture kuka je pad. Uspoređujući nalaze kompjutorizirane tomografije i konvencionalne radiografije zaključujemo da rendgenogram dobro dijagnosticira frakture, dok su CT-om dobro prikazane udružene ozljede kao što su zglobni izljevi, hematomi i subluksacije.

ZAKLJUČAK: Obje dijagnostičke metode pružaju gotovo podjednake dijagnostičke informacije prilikom dijagnoze frakture kuka i kao takve su komplementarne. Za kvalitetno dijagnosticiranje potrebno je prvenstveno adekvatno stručno znanje kao i ispravan klinički pristup te kvalitetna komunikacija na relaciji pacijent-inžinjer medicinske radiologije- specijalist radiolog.

Ključne riječi: fraktura kuka, usporedba, konvencionalna radiografija, kompjuterizirana tomografija

Osoba za razmjenu informacija:

Doc. dr. Miro Miljko

miro.miljko@gmail.com

\section{UVOD}

Zglob kuka je jedan od najvažnijih zglobova i ujedno najveći zglob ljudskog tijela. Ima nezaobilaznu ulogu u razvoju i očuvanju pravilne arhitekture cjelokupnog lokomotornog sustava, odnosno statike i simetrije tijela. Kao takav, od iznimne važnosti predstavlja ključni čimbenik normalnog kretanja i fizičke aktivnosti u cjelini (1).

Zglob kuka poseban je kuglasti zglob s tri glavne osi kretanja. On povezuje gornji kraj bedrene kosti (femur) i zdjeličnu kost (pelvis). Konkavno zglobno tijelo zgloba je acetabulum, a konkveksno je glava bedrene kosti (caput femoris).

Prijelom ili fraktura označava ozljedu koja dovodi do prekida koštanog kontinuiteta pod djelovanjem vanjske sile. Fraktura se može klasificirati kao direktna fraktura (uzrokuje lom na mjestu udara ili ranjavanja), i indirektna fraktura (uzrokuje ozljedu na mjestu udaljenom od točke djelovanja sile, npr. 
lom klavikule prilikom pada na ispruženu ruku) (2). Tamo gdje koštani kontinuitet nije u cijelosti prekinut imamo fisuru (frakturna pukotina koja ne mijenja oblik kosti) (3).

Stupanj, veličina, mjesto i opsežnost loma određuju njegovu daljnju klasifikaciju, odnosno da li se radi o djelomičnoj ili kompletnoj frakturi i daljnjoj kliničkoj opservaciji. Uobičajene djelomične frakture jesu ispupčena i naprslina (4).

Među metodama dijagnostike frakture kuka, svakako je najčešće prisutna primjena konvencionalne radiografije. Klasična radiografija brzo, efikasno i bez previše nepotrebnog ozračivanja dijagnosticira lomove i osigurava kvalitetne inofrmacije za daljnje zbrinjavanje unesrećene osobe. Snimak nam daje uvid u trenutno stanje kosti, vrstu loma, položaje fragmenata i eventualno zahvaćenje susjednih zglobova (5).

Kompjutorizirana tomografija nudi mogućnost prikaza zgloba kuka u tri dimenzije. Međutim, CT može imati dodatnu korist u volumetrijskim izmjerima, ali zbog cijene same pretrage i slabije rezolucije od klasičnog radiograma ne koristi se toliko često kao klasični rendgenski aparat, a osim toga pacijenti su izloženi visokim dozama zračenja. On nam omogućuje dobar anatomski prikaz odnosa i izgleda te položaja zglobnih tijela. CT često može prikazati frakture (posttraumatske) koje nisu bile vidljive na klasičnoj rendgenskoj snimci (5).

Prednost se ipak u velikoj većini slučajeva pridaje klasičnom konvencionalnon rednegenogramu zbog niske cijene izrade, lakoj dostupnosti opreme, ali i malim dozama zračenja u odnosu na MSCT pretragu. (6)

\section{CILJ ISTRAŽIVANJA}

1. Ispitati valjanost konvencionalnih snimaka kod prijeloma kuka

2. Ispitati valjanost $\mathrm{CT}$ nalaza kod prijeloma kuka

3. Usporediti konvencionalne snimke i nalaze CT-a kod prijeloma kuka

\section{ISPITANICI I METODE}

$\mathrm{Za}$ potrebe našeg istraživanja provedeno je retrospektivno istraživanje na Kliničkom zavodu za radiologiju Sveučilišno-kliničke bolnice (SKB) Mostar u Mostaru. Provedeno istraživanje odnosi se na period od 10.01.2014.g. do 21.08.2014. godine. Istraživanjem je obuhvaćeno 40 pacijenata. Svim bolesnicima je učinjen konvencionalni snimak i klinički pregled CT kuka.

Obrađeni su sljedeći parametri: dob, spol i način ozljede. Tijekom ispitivanja analizirana je struktura ispitanika po dobu, spolu i vrsti pretrage kao i radiološkim dijagnozama.

Snimanje na Multislice computed tomography (MSCT) je obavljeno na uređaju Somatom Sensatiom 16 tvrtke Siemens (Erlangen,Germany) koristeći standardni protokol te odgovarajuće kose koronarne i kose transverzalne rekonstrukcijske nalaze.

\section{REZULTATI}

Iz tablice br. 1 vidljivo je da je najveći broj (35\%) ispitanika starosne dobi između 70-te i 79-te godine vršilo snimanje kuka dok su pacijenti starosne dobi između 10-19 i 30-39 godina najmanje zastupljeni u ovom istraživanju.

Tablica 1. Raspodjela ispitanika prema starosnoj dobi

\begin{tabular}{ccc}
\hline Starost u godinama & Broj ispitanika & Udio (\%) \\
\hline $10-19$ & 2 & 5 \\
$20-29$ & 3 & 7,5 \\
$30-39$ & 4 & 10 \\
$40-49$ & 2 & 5 \\
$50-59$ & 4 & 10 \\
$60-69$ & 11 & 27,5 \\
$70-79$ & 14 & 35 \\
Ukupno: & 40 & 100 \\
\hline
\end{tabular}

Tablica br. 2 ukazuje da je muški spol zastupljeniji u ovom istraživanju što znači da je i češće vršio rendgenska i CT snimanja prilikom radiološke opservacije (65\%).

Tablica 2. Spol ispitanika

\begin{tabular}{ccc}
\hline Spol ispitanika & Broj ispitanika & Udio (\%) \\
\hline Muški & 26 & 65 \\
Ženski & 14 & 35 \\
Ukupno: & 40 & 100 \\
\hline
\end{tabular}


Iz tablice br. 3 je vidljivo da je najveći broj pacijenata stradao od posljedica mehaničkog pada (55 $\%)$, slijede prometne nesreće (27,5\%), dok je sedam pacijenata zadobilo frakturu kuka zbog sportske ozljede $(17,5 \%)$.

Tablica 3. Raspodjela ispitanika prema načinu nastanka ozljede

\begin{tabular}{ccc}
\hline Način nastanka ozljede & Broj ispitanika & Udio (\%) \\
\hline Sportska ozljeda & 7 & 17,5 \\
Pad & 22 & 55 \\
Prometna nesreća & 11 & 27,5 \\
Ukupno: & 40 & 100 \\
\hline
\end{tabular}

Iz tablice br. 4 uočavamo da je najčešća vidljiva dijagnoza prilikom konvencionalne radiografije pri sumnji na prijelom kuka upravo; fraktura vrata femura (35\%), slijedi fraktura vrata femura sa udruženom frakturom velikog trohantera (25\%), slijede ih i fraktura acetabuluma (20 \%) i luksacija (12,5\%), dok je kod tri pacijenta vidljivo proširenje zglobnog prostora kuka $(7,5 \%)$.

Tablica 4. Dijagnoza dobivena konvencionalnom radiografijom

\begin{tabular}{|c|c|c|}
\hline Dijagnoza & $\begin{array}{c}\text { Broj napravljenih } \\
\text { pretraga }\end{array}$ & Udio (\%) \\
\hline Fraktura acetabuluma & 8 & 20 \\
\hline Fraktura vrata femura & 14 & 35 \\
\hline $\begin{array}{l}\text { Fraktura vrata femura }+ \\
\text { fraktura velikog trohantera }\end{array}$ & 10 & 25 \\
\hline Luksacija & 5 & 12,5 \\
\hline $\begin{array}{l}\text { Proširen zglobni prostor } \\
\text { kuka }\end{array}$ & 3 & 7,5 \\
\hline Ukupno : & 40 & 100 \\
\hline
\end{tabular}

Iz tablice br. 5. vidljivo je da je kod prijeloma kuka također najčešća ozljeda fraktura vrata femura (30 $\%)$, slijedi fraktura vrata femura sa frakturom velikog trohantera $(25 \%)$ te fraktura acetabuluma (20 $\%)$. Od fraktura acetabuluma najčešće su frakture prednje kolumne (5). Nešto rijeđe su bile luksacije kuka (12,5\%), sublukascija i zglobni izljev kuka (5 $\%)$, dok je svega jedan pacijent imao dijagnosticiran hematomni izljev u okolnim mišićnim strukturama. $(2,5 \%)$
Tablica 5. Dijagnoza dobivena kompjutoriziranom tomografijom

\begin{tabular}{|c|c|c|}
\hline Dijagnoza & $\begin{array}{c}\text { Broj napravljenih } \\
\text { pretraga }\end{array}$ & Udio (\%) \\
\hline Fraktura vrata femura & 12 & 30 \\
\hline $\begin{array}{c}\text { Fraktura vrata } \\
\text { femura + fraktura velikog } \\
\text { trohantera }\end{array}$ & 10 & 25 \\
\hline Subluksacija kuka & 2 & 5 \\
\hline Luksacija kuka & 5 & 12,5 \\
\hline Zglobni izljev kuka & 2 & 5 \\
\hline $\begin{array}{l}\text { Hematomi u okolnim } \\
\text { mišicíima }\end{array}$ & 1 & 2,5 \\
\hline $\begin{array}{c}\text { Fraktura prednje kolumne } \\
\text { acetabuluma }\end{array}$ & 5 & 12,5 \\
\hline $\begin{array}{c}\text { Fraktura stražnje kolumne } \\
\text { acetabuluma }\end{array}$ & 2 & 5 \\
\hline $\begin{array}{l}\text { Fraktura prednje i stražnje } \\
\text { kolumne acetabuluma }\end{array}$ & 1 & 2,5 \\
\hline Ukupno: & 40 & 100 \\
\hline
\end{tabular}

\section{RASPRAVA}

Od ukupno 40 ispitanika,najveći je broj pacijenata bio treće životne dobi, između 60 i 79 godina (ukupno $62,5 \%$ ). Taj nam je podatak na početku sugerirao da je većina fraktura kuka bilo uzrokovano naglim trzajnim i mehaničkim ozljedama uslijed degenerativnih promjena. Naime, kao najčešći uzroci nastanka ozljede kuka bili su padovi i prometne nesreće s preko $82 \%$ zastupljenosti u ovom istraživanju.

Od 40 ispitanika, 26 je bilo muškaraca, odnosno $65 \%$, a žena 14 , odnosno $35 \%$ ispitanih. To nikako ne mora značiti da su muškarci više podložni ozljedama i prijelomima kuka, iako je indikativno da su ovom istraživanju bili više zastupljeniji nego ženski spol.

Prilikom snimanja kuka konvencionalnom radiografijom istraživanje je pokazalo da je najveći broj ispitanika zadobio frakturu vrata femura, njih 14, slijede frakture vrata femura sa udruženom frakturom velikog trohantera te frakturom acetabuluma. Te tri frakture su činile $80 \%$ svih ozljeda ovog istraživanja.

Kod pacijenata koji su vršili snimanje kuka kompjuteriziranom tomografijom (CT), također je kod najvećeg broja dijagnosticirana fraktura vrata femura, acetabuluma i velikog trohantera čineći $80 \%$ 
ukupnih prijeloma. U odnosu na konvencionalnu radiografiju,u ovom slučaju CT je pokazao veću preciznost u točnoj lokalizaciji mjesta prijeloma.

Tijekom istraživanja zaključili smo da je muški spol podložniji ozljedama kuka u odnosu na ženski spol. Nakon istraživanja zaključili smo da su sve radiološke metode podjednako bile uključene tijekom dijagnoze frakture kuka. U istraživanje je također bilo uključeno i način nastanka samog patološkog stanja, čime smo utvrdili da je najčešći uzrok nastanka frakture kuka mehanička ozljeda, odnosno pad. S obzirom na dob ispitanika koji su bili uključeni u istraživanje, najveći broj ispitanika je u dobi od 70-79 godina, a usporedbom nalaza MSCT-a i konvencionalnog rendgena dokazano je da obje dijagnostičke metode pružaju gotovo podjednake informacije prilikom dijagnoze frakture zgloba kuka, $s$ naglaskom kako MSCT nalaz ipak pruža kvalitetniji prikaz i uvid u sitne muskulo-skeletne promjene.

\section{ZAKLJUČAK}

Frakture kuka najčešće pogađaju osobe u dobi između 70 i 79 godina, starije životne dobi i muške populacije. Najčešći uzroci navedenih fraktura jesu pad, prometne nesreće i sportske ozljede.

Uloga konvencionalne radiografije i komputorizirane tomografije je izrazito značajna u medicinskoj dijagnostici ovakvih tipova prijeloma, osobito fraktura kuka.

Istraživanje je pokazalo da je konvencionalni radiografski snimak u dva smjera sasvim dovoljan za osnovnu kvalitetnu dijagnozu kod ozljeda zdjelice, odnosno kuka, i kao takvi su visoko pouzdani. Kompjutorizirana tomografija je također prikazala identične frakture kao u prethodnom opisu, što je visok znak podudarnosti obje pretrage, uz jednu vrlo bitnu značajku. MSCT-om je moguć detaljniji uvid i prikaz u točniju i precizniju lokalizaciju ozljede, odnosno frakture. Tako smo, primjerice, kod ozljede acetabuluma dobili točan i jasan uvid u mjesto i tip frakture, što nije bio slučaj kod konvencionalnog rendgena.

Daljnjom analizom MSCT nalaza vidljivi su i sitni patološki procesi koje rendgenom ne bi bilo moguće vidjeti, kao što su zglobni izljev kuka, hematomi u okolnim mišićnim regijama i sl.

Prednosti konvencionalne radiografije u odnosu na CT jesu smanjeni troškovi izrade, ušteda novca, vremena, ali i najveća značajka, neusporedivo manja količina ioniziranog zračenja u odnosu na kompjutoriziranu tomografiju.

Prednost CT-a je i mogućnost trodimenzionalnog prikaza, što pomaže kliničaru (ortopedu i traumatologu) u boljoj prostornoj orijentaciji.

\section{LITERATURA}

1. Krmpotić - Nemanić J., Anatomija čovjeka, Medicinska naklada Zagreb 1993.

2. Fanghanel J. -Pera F. - Vinter I., Waldeyerova anatomija čovjeka, Golden marketing Zagreb 2009.

3. Pećina M., Bojanić I. Overuse Injuries of the Muculoskeletal system. 2nd ed.Boca Raton, CRC Press, 2003.

4. Štalekar H. Općenito o prijelomima, http://www.medri.uniri.hr/katedre/Kirurgiju/ autorizirana\%20predavanja/stalekar/Stalekar. pdf

5. Mašković J. i prof.dr. Janković S., Radiologijska aparatura, Mostar 2003.

6. Donovan A., Schweitzer M., Imaging Musculosceletal Trauma: Interpretration and reporting, Wiley 2012. 


\title{
HIP FRACTURE: COMPARING THE REPORTS OF CONVETIONAL RADIOGRAPHY AND COMPUTED TOMOGRAPHY
}

\author{
Marko Krpan, Miro Miljko \\ Faculty of Health Studies, University of Mostar
}

\begin{abstract}
INTRODUCTION: The hip joint is one of the most important and biggest joints in the human body. It has an inevitable role in the development and preservation of the right architecture of the entire musculoskeletal system, with reference to static and symmetry of the human body. Hip fracture is still an extremely important personal, public health and family problem as it largely impairs the patient's quality of life and on the other hand requires considerable costs of the health system.

SUBJECTS AND METHODS: The objective of the research was to compare the values of conventional radiography and computed tomography in the diagnosis of hip fractures and injuries. For the purposes of graduate work we conducted a retrospective research at the Department of Radiology at the University Clinical Hospital in Mostar. The research was carried out in the period from January 10 to August 21, 2014. The study included 40 patients with hip fractures. All of the patients underwent a specialist examination by an orthopaedic, an X-ray scan, a MSCT, and were diagnosed with hip fractures.

RESULTS: The results indicate that hip fractures more frequently affect the elderly male population. The most common cause of the hip fracture is the fall. When comparing the reports of conventional radiography and computed tomography we can conclude that the roentgenogram identifies the nature of the fracture while the CT scan shows all associated injuries, such as joint effusions, hematomas and partial dislocations.

CONCLUSION: The study demonstrated that both of the mentioned methods provide almost equal information in the diagnosis of the hip fractures, and as such are complementary. A quality diagnosis primarily needs an adequate professional knowledge as well as a correct approach and a good communication between a patient, an engineer of medical radiology, and a radiologist.
\end{abstract}

Key words: hip fracture, conventional radiology, computed tomography

Correspondence:

Miro Miljko, MD, PhD

e-mail: miro.miljko@gmail.com 